\title{
PROGRAM PEMBERDAYAAN MASYARAKAT MELALUI PENGOLAHAN BANK SAMPAH DI DESA MONTONG BAAN KECAMATAN SIKUR KABUPATEN LOMBOK TIMUR
}

\author{
Fitri Amelia Putri ${ }^{1}$, Serly Surjan Ekayanti², Vandesty Harummiswari $\mathrm{H}^{3}$, Aris Doyan ${ }^{4}$ \\ 1,2,4 Fakultas Keguruan dan IImu Pendidikan, Unirversitas Mataram, \\ ${ }^{3}$ Fakultas Ekonomi dan Bisnis, Unirversitas Mataram, Mataram, \\ *Korespodensi e-mail : arisdoyan@yahoo.co.id
}

\begin{abstract}
ABSTRAK. Desa Montong Baan merupakan salah satu desa tertua yang ada di Kecamatan Sikur, Kabupaten Lombok Timur, Nusa Tenggara Barat. Desa ini berada ditempat yang strategis dan mudah dijangkau dari ibu kota kabupaten maupun provinsi, karena berada di tepi Jalan Negara Masbagik dan Mataram. Kendala yang terlihat di Desa Montong Baan adalah kurangnya kesadaran masyarakat tentang kebersihan lingkungan dan pengelolaan sampah, serta disetiap dusun belum tersedia tempat penampungan sampah. Sehingga, banyak terlihat sampah-sampah yang berserakan padahal sudah terdapat lokasi pengolahan sampah (Bank sampah) di Desa Montong Baan itu sendiri. Alternatif yang dapat dilakukan untuk mengatasi kendala tersebut adalah Pemberdayaan Masyarakat Melalui Program Bank Sampah MACADAS (Masyarakat Cerdas Daur Sampah) dan Sosialisasi Peduli Lingkungan. Tujuan dari program ini adalah untuk membantu menangani pengolahan sampah dan masyarakat dapat mengubah sampah menjadi sesuatu yang lebih berguna, misalnya untuk kerajinan atau sesuatu yang memiliki nilai ekonomis serta masyarakat bisa sadar akan pentingnya peduli terhadap lingkungan. Metode yang digunakan adalah survei bank sampah yang sudah ada di Desa Montong Baan, persiapan program, sosialisasi bank sampah dan peduli lingkungan, pembuatan kerajinan dari bahan bekas, monitoring dan evaluasi. Hasil yang diharapkan dari program pemberdayaan dan sosialisasi ini adalah masyarakat Desa Montong Baan dapat merubah paradigma lama menjadi paradigma baru tentang sampah, yang tentunya akan berdampak menjadi lebih baik bagi masyarakat, lingkungan dan perekonomian masyarakat itu sendiri..
\end{abstract}

Kata Kunci: Bank Sampah, MACADAS, Pengolahan Sampah, Peduli Lingkungan

\section{PENDAHULUAN}

Sampah adalah sesuatu yang tidak dipergunakan, tidak dapat dipakai, tidak disenangi lagi dan harus dibuang, maka sampah harus dikelola dengan sebaik-baiknya, sedemikian rupa, sehingga hal negatif bagi kehidupan tidak sampai terjadi (Azwar, 1990: 53). Sampah merupakan bagian dari masalah lingkungan karena pertambahan volume sampah berkolerasi dengan pertambahan jumlah penduduk dan upaya untuk mengurangi sampah masih terbatas (Soemarwoto, 2001). Ditengah kepadatan aktifitas manusia, penanganan sampah masih menjadi permasalah serius yang belum bisa ditangani dengan tuntas. Hal ini dikarenakan rata-rata tiap orang perhari dapat menghasilkan sampah satu sampai dua $\mathrm{Kg}$ sampah dan akan terus bertambah sejalan dengan meningkatnya kesejahteraan dan gaya hidup masyarakat. Sampah yang tidak mendapat penanganan serius bisa mengakibatkan pencemaran, baik polusi udara, polusi air, maupun polusi tanah (Hadisuwito, 2007). Berdasarkan lokasinya, sampah dapat diklarifikasikan menjadi dua yaitu sampah kota (urban), yaitu sampah yang terkumpul di kota - kota besar dan sampah daerah, yaitu sampah yang terkumpul di 
daerah - daerah di luar perkotaan, misalnya desa, di daerah pemukiman dan di pantai (Hadiwiyoto, 1983).

Masyarakat harus meninggalkan cara lama yang hanya membuang sampah dengan mendidik dan membiasakan masyarakat memilah, memilih, dan menghargai sampah sekaligus mengembangkan ekonomi kerakyatan melalui pengembangan bank sampah (Tallei,dkk, 2013). Menurut Peraturan Menteri Negara Lingkungan Hidup RI Nomor 13 Tahun 2012 pasal 1 ayat 2 tentang pedoman pelaksanaan 3R (Reduce, Reuse, dan Recycle) melalui bank sampah yaitu "Bank sampah adalah tempat pemilahan dan pengumpulan sampah yang dapat didaur ulang atau digunakan ulang yang memiliki nilai ekonomi”. Bank sampah adalah tempat menabung sampah yang telah terpilah menurut jenis sampah. Cara kerja bank sampah pada umumnya hampir sama dengan bank lainnya ada nasabah, pencatatan pembukuan dan managemen pengelolaannya. Apabila dalam bank umum yang disebabkan nasabah adalah uang, akan tetapi dalam bank sampah yang disebabkan adalah sampah yang bernilai ekonomis (Aryenti, 2011).

Masyarakat dapat sewaktu-waktu mengambil uang pada tabungannya saat tabungannya sudah terkumpul banyak. Imbalan yang diberikan kepada penabung tidak hanya berupa uang, tetapi adapula yang berupa bahan makanan pokok seperti gula, sabun, minyak dan beras. Bank sampah memberikan manfaat ekonomi yaitu masyarakat memperoleh uang dari sampah yang ditabung pada bank sampah yang dapat diambil dalam kurun waktu tertentu sesuai aturan di setiap bank sampah. Manfaat ekonomi juga dapat diperoleh masyarakat melalui kegiatan daur ulang sampah menjadi kerajinan yang dapat dijual. Seperti tas, dompet, pot, bantal dan lain sebagainya. Bank sampah juga memberikan manfaat sosial yaitu pertama, melalui sosialisasi dari bank sampah, masyarakat dianjurkan untuk memilah sampah, antara sampah organik dan sampah anorganik. Kedua, masyarakat diarahkan pada pola pikir kreatif dalam mengolah sampah dengan mengubahnya menjadi barang yang bisa dimanfaatkan kembali. Ketiga, bank sampah sebagai organisasi pemberdayaan masyarakat, menggerakkan masyarakat untuk lebih memperhatikan lingkungan terutama terhadap sampah (Suwerda, 2012: 19).

Bank sampah berdiri dikarenakan adanya keprihatinan masyarakat akan lingkungan hidup yang semakin lama semakin dipenuhi dengan sampah, baik sampah organik maupun anorganik. Semakin banyak sampah akan menimbulkan semakin banyak masalah. Oleh karenanya, diperlukan pengolahan seperti membuat sampah menjadi bahan yang lebih berguna. Pengelolaan sampah dengan sistem bank sampah ini diharapkan mampu membantu pemerintah dalam menangani sampah dan meningkatkan ekonomi masyarakat (Suryani, 2014). Pengetahuan, sikap, dan keterampilan warga mengelolah sampah rumah tangga untuk melakukan daur ulang juga menjadi hal penting dalam pengelolaan sampah. Pengolahan sampah rumah tangga yang termasuk kategori sampah organik dapat dijadikan kompos sedangkan sampah rumah tangga anorganik ditabung ke bank sampah untuk di daur ulang kembali dan dapat dijadikan bahan yang bernilai ekonomis (Jumar,dkk. 2014).

Dengan banyaknya sampah-sampah yang berserakan di setiap harinya terutama sampah rumah tangga, maka seharusnya bank sampah yang sudah tersedia harus dimanfaatkan dengan baik yang akan memberikan banyak manfaat. Selain akan mengurangi sampah-sampah yang terlalu banyak, dengan adanya bank sampah ini juga dapat meningkatkan kreatifitas diri dan meningkatkan perekonomian masyarakat. Akan tetapi banyak masyarakat yang tidak tahu akan keberadaan bank sampah di Desa Montong Baan tersebut, sehingga masyarakat menjual sampah yang sudah di pilah 
kepada pengepul dari luar. Berdasarkan latar belakang di atas kami melakukan pengabdian KKN yaitu "Program Pemberdayaan Masyarakat Melalui Pengolahan Bank Sampah di Desa Montong Baan Kecamatan Sikur Kabupaten Lombok Timur". Pengabdian KKN ini bertujuan untuk meningkatkan pemberdayaan masyarakat melalui pengolahan bank sampah dengan baik dan benar.

Hasil yang diharapkan dari Pengabdian KKN ini adalah dapat memberikan nilai jual pada sampah anorganik yang telah di pilah, menambah nilai guna terhadap sampah - sampah anorganik, mengurangi sampah - sampah yang banyak dan dapat meningkatkan kreatifitas masyarakat yang dimana masyarakat dapat merubah sampah menjadi barang yang berguna seperti celengan, tas, dompet, tempat air, pot dan lain sebagainya.

\section{ANALISIS PERMASALAHAN}

\section{METODE PELAKSANAAN}

\section{Waktu dan Tempat}

Kegiatan dilakukan selama 25 kali pertemuan di mulai sejak hari rabu, tanggal 30 Januari 2019 sampai dengan hari Rabu, 13 Maret 2019 di Desa Montong Baan, Kecamatan Sikur, Kabupaten Lombok Timur.

\section{Alat dan Bahan}

1) Alat untuk Bank Sampah

Alat yang digunakan dalam Program ini adalah karung, timbangan, buku tabungan dan buku kas.

\section{2) Alat dan Bahan untuk Kerajinan}

Alat yang digunakan dalam Program ini adalah gunting, silet, isolasi dan lem tembak. Sedangkan bahan yang digunakan adalah botol bekas, gelas plastik yang bekas, kain flanel, dan kawat pita.

3) Alat dan Bahan untuk Sosialisasi peduli lingkungan

Alat yang digunakan dalam Program ini adalah microphon dan sound sistem. Sedangkan bahan yang digunakan adalah browsur.

Prosedur Kerja Pemberdayaan bank sampah dan sosialisasi perduli lingkungan Prosedur Kerja Pemberdayaan bank sampah adalah :
a. Masyarakat mengumpulkan sampah yang sudah di pilah sebelumnya
b. Melakukan registrasi / pendaftaran
c. Sampah ditimbang lalu dicatat dan dibukukan
d. Nasabah menerima buku tabungan
e. Sampah diangkut oleh pengepul 


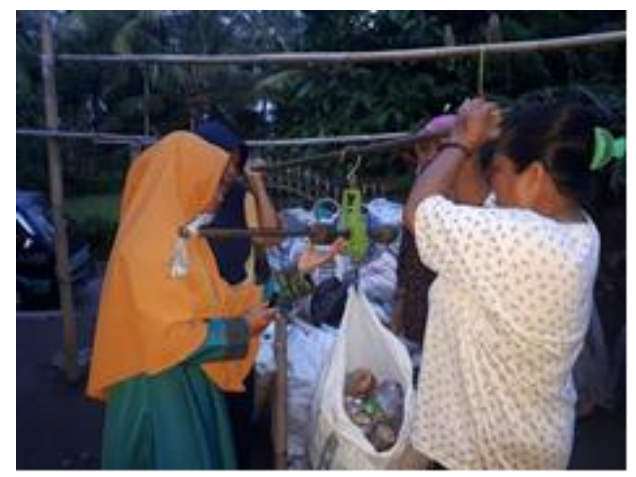

Gambar 1. Prosedur Bank sampah

1) Prosedur Kerja Pemberdayaan Sosialisasi Peduli Lingkungan Mempersiapkan tempat sosialisasi peduli lingkungan
a. Menyiapkan tempat berlangsungnya sosialisasi
b. membuat materi sosialisasi
c. menyiapkan alat berupa microphone dan sound sistem

2) Prosedur Kerja Kerajinan kerajinan yang diterapkan salah satunya adalah pembuatan celengan dari botol bekas. Prosedur kerjanya adalah :
a. Menyiapkan alat dan bahan yang diperlukan
b. Menempelkan kain flanel pada botol bekas menggunakan botol bekas.
c. Melubangi botol bekas menggunakan silet atau gunting

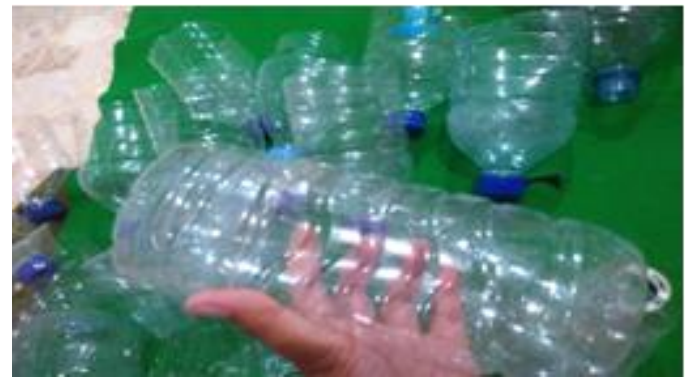

Gambar 2. Proses kerajinan berupa celengan

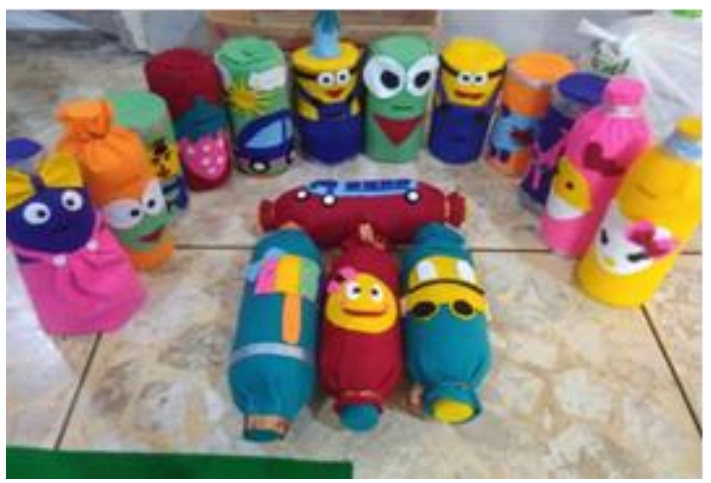

Gambar 3. Hasil kerajinan celengan 


\section{Bentuk Kegiatan}

Bentuk kegiatan secara keseluruhan ini adalah 1) Persiapan program, 2) Sosialisasi tentang peduli lingkungan, 3) Pelatihan Pembuatan kerajinan dari sampah, 4) Monitoring dan evaluasi

\section{Metode Pengumpulan dan Analisis Data}

Metode pengumpulan data pada program ini adalah dengan survei jumlah sampah dan kondisi lingkungan sekitar, analisis data menggunakan deskriptif kualitatif.

\section{HASIL DAN PEMBAHASAN}

Program pemberdayaan masyarakat melalui pengolahan bank sampah dan sosialisasi peduli lingkungan di Desa Montong Baan dilakukan secara terstruktur dan melibatkan masyarakat secara langsung.

\section{Pelaksanaan Program Pemberdayaan Masyarakat Melalui Pengolahan Bank Sampah}

Kegiatan pemberdayaan masyarakat melalui pengolahan bank sampah ini dimulai dengan persiapan program yang meliputi survei lokasi. Hasil survei menunjukkan bahwa kendala yang dihadapi masyarakat Montong Baan antara lain 1) Tidak adanya lokasi pembuangan/ pengumpulan sampah sementara, 2) banyak volume sampah setiap harinya, 3) tidak adanya alat penghancur sampah, 4) kurangnya pengepul, 5) kurangnya minat masyarakat untuk mendaur ulang sampah. Tahap selanjutnya adalah persiapan instrumen monitoring dan evaluasi yaitu pengetahuan masyarakat, selanjutnya perijinan dan pembahasan program bersama masyarakat Montong Baan, Kecamatan Sikur, Kabupaten Lombok Timur.

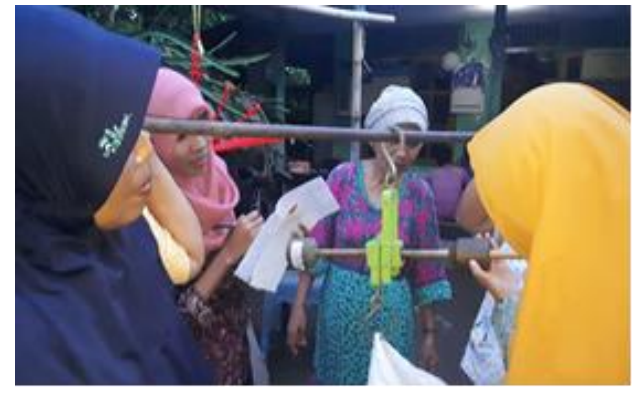

Gambar 4. Bank Sampah 1

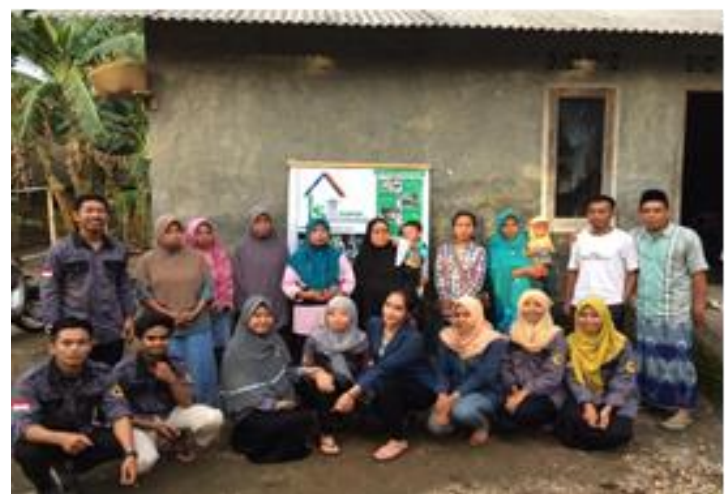

Gambar 5. Bank sampah 2 


\section{Pelaksanaan Program Pemberdayaan Masyarakat Melalui Sosialisasi Peduli Lingkungan}

Pelaksanaan program pemberdayaan masyarakat melalui pengolahan bank sampah dan sosialisasi peduli lingkungan di desa Montong Baan dilakukan di Dusun Montong Atas dan Dusun Mentaum. Pertama menjelaskan tentang apa itu bank sampah dan prosedur kerjanya. Selanjutnya sosialisasi peduli lingkungan serta menjelaskan tentang bagaimana pemisahan limbah sampah rumah tangga, sampah organik dan anorganik serta menjelaskan bagaimana tahap pembuatan kerajinan menggunakan bahan bekas yang dimana dihadiri oleh masyarakat di Dusun Montong Atas dan Dusun Mentaum. kegiatan ini diadakan untuk menumbuhkan dan meningkatkan kesadaran masyarakat mengenai pengolahan sampah dan kebersihan lingkungan agar dapat membedakan jenis sampah mana yang dapat didaur ulang dan tidak dapat didaur ulang.

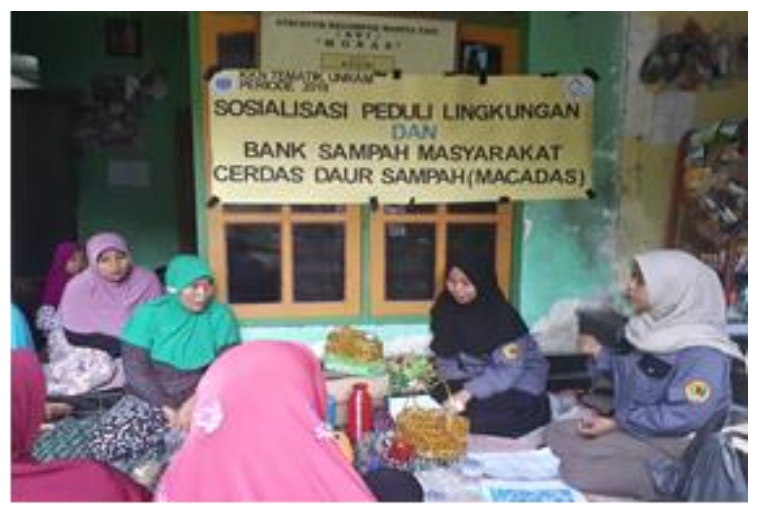

Gambar 5. Sosialisasi Peduli Lingkungan

\section{Monitoring dan Evaluasi}

Monitoring dan evaluasi kontinu dilakukan bersamaan dengan pedamping program. Hasil monitoring dan evaluasi program secara umum menunjukan bahwa masyarakat mampu memanfaatkan dan mengolah sampah menjadi sesuatu yang memiliki harga ekonomis dan bermanfaat.

\section{KESIMPULAN}

Simpulan dari program-program ini adalah Program Pemberdayaan Masyarakat Cerdas Daur Sampah atau Bank Sampah. Masyarakat Desa Montong Baan sadar akan pentingnya peduli terhadap lingkungan yaitu dengan cara masyarakat menabung sampah-sampah yang sudah di kumpulkan ke Bank Sampah yang sudah tersedia di Desa Montong Baan ini. Selain itu masyarakat dapat memanfaatkan sampah-sampah terutama sampah anorganik menjadi berbagai macam kerajinan tangan salah satu diantaranya berupa pembuatan celengan dari botol bekas sehingga masyarakat dapat merubah sampah menjadi sesuatu yang bernilai ekonomis, dan dapat meningkatkan kreatifitas masyarakat.

Program pemberdayaan masyarakat melalui sosialisasi peduli lingkungan. Masyarakat Desa Montong Baan sadar akan peduli lingkungan dan kebersihan lingkungan di sekitarnya. Masyarakat juga dapat membedakan berbagai jenis sampah, mana sampah yang dapat di daur ulang dan mana yang tidak dapat di daur ulang dan dapat membedakan atau memisahkan sampah organik dan anorganik serta masyarakat dapat mengetahui dan menerapkan sistem 3R yang dimana sistem ini 
sangat membantu dalam pengelolaan sampah sehingga dapat mewujudkan lingkungan yang bersih dan adanya kesadaran akan peduli lingkungan.

\section{UCAPAN TERIMA KASIH}

Pengabdian KKN ini dapat terlaksana atas kerjasama dari pihak LPPM, pihak Desa Montong Baan dan dukungan dari dosen pembimbing lapagan Bapak Drs. Aris Doyan, M. Si., Ph. D serta rekan-rekan seperjuangan KKN Universitas Mataram Sdr. Aston Villa Roi Pandu, Sdr. Farizki Fairuzzabadi, Sdr. Febi Fitra Azmi, Sdr. Harrmila Adhani, Sdr. Nila Sari, Sdr. sri Agustina Mayang Sari, dan Sdr. Wahbi, kami mengucapkan terimakasih atas bantuan rekan-rekan dalam menyusun artikel ini.

\section{REFERENSI}

Aryenti. 2011. Peningkatan peran serta masyarakat melalui gerakan menabung pada bank sampah di Kelurahan Babakan Surabaya, Kiaracondong Bandung. Jurnal Pemukiman, vol. 6 No.1 April 2011:40 $-46$.

Azwar, Azrul. 1990. Pengantar ilmu lingkungan. Jakarta: Mutiara Sumber Widya.

Hadisuwito, S. 2007. Membuat pupuk kompos cair. Agromedia Pustaka. Jakarta.

Hadiwiyoto, Soewodo. 1983. Penanganan dan Pemanfaatan Sampah. Jakarta: Yayasan Idayu.

Jumar, Fitriyah, N; dan Kalalinggie, R; 2014. Strategi Pengelolaan Sampah Rumah Tangga di Kelurahan Log Bahu Kecamatan Sungai Kunjang Kota Samarinda. Jurnal administratif reform, 2 (1) : 771-782.

Peraturan Menteri Negara Lingkungan Hidup Nomor 13 Tahun 2012 pasal 1 ayat 2 tentang pedoman pelaksanaan Reduce, Reuse, Recycle (melalui bank sampah).

Soemarwoto, O. 2001. Ekologi Lingkungan dan Pembangunan. Jakarta: Djambatan.

Suryani, Anih Sri. 2014. Peran Bank Sampah Dalam Efektivitas pengelolaan Sampah (Study Kasus Bank Sampah Malang). Jakarta: Jurnal Bank Sampah.

Suwerda, B. 2012. Bank Sampah (Kajian Teori dan Penerapan). Yogyakarta: Pustaka Rihama.

Tallei, Dkk. 2013. Local Community Based Initiatives of Waste Management Activities on Bunaken Island in North Sulawesi, Indonesia. Research Journal of Environmental and earth sciences, 5(12):737-743. 